\title{
PORT ADAPTATION TO SEA LEVEL RISE: LESSONS FROM PRESENT EXAMPLES OF LAND SUBSIDENCE
}

\author{
Miguel Esteban, The University of Tokyo, esteban.fagan@gmail.com \\ Hiroshi Takagi, Tokyo Institute of Technology, takagi@ide.titech.ac.jp \\ Dyah Fatma, Planning and Development Workshop, dyah.fatma@gmail.com \\ Takahito Mikami, Waseda University, takahito8765@gmail.com \\ Paolo Valenzuela, The University of Tokyo, valenzuela.venpaolo@gmail.com \\ Erick Avelino, The University of Tokyo, john.avelino@s.k.u-tokyo.ac.jp \\ Richard Crichton, The University of Tokyo, crichton.richard@gmail.com \\ Laurice Jamero, The University of Tokyo, laujamero@gmail.com \\ Christopher Chadwick, John Moores University, U.K., chris@thehatch.tv \\ Motoharu Onuki, The University of Tokyo, onuki@k.u-tokyo.ac.jp
}

\begin{abstract}
INTRODUCTION
According to the Intergovernmental Panel on Climate Change $5^{\text {th }}$ Assessment Report, or IPCC 5AR (2013), sea level is rise (SLR) could be in the order of 26 to 98 $\mathrm{cm}$ by 2100 . However, more onerous predictions, such as those set forth in recent probabilistic process-based models by Kopp et al. (2017), or Bars et al., (2017), indicate that SLR could be almost in the order of almost $3 \mathrm{~m}$ by the end of the $21^{\text {st }}$ century.
\end{abstract}

As a result of sea level rise a number of authors have stated that many ports and coastal communities would be forced to relocate or attempt expensive adaptation countermeasures (Yamamoto and Esteban, 2016). However, most of the forecasted problems and their knock-on consequences on coastal communities remain hypothetical, despite a number of past examples of relative sea level rise due to earthquake induced subsidence or groundwater extraction (Jamero et al, 2016, 2017, Takagi et al., 2016, Esteban et al., 2017).

In order to better understand the consequences of future sea level rise the authors have analysed the effects of two instances land subsidence that have taken place in the $20^{\text {th }}$ and early $21^{\text {st }}$ century, and the adaptation measures that ports and other low-lying areas have adopted in the northern Japanese region of Tohoku following the 2011 Earthquake Tsunami, and Jakarta in Indonesia (where groundwater extraction has been inducing rates of subsidence of $10-20 \mathrm{~cm}$ per year in several parts of the city, Takagi et al, 2017). To date, the authors are not aware of any other work that has systematically attempted to learn from real examples of land subsidence as a proxy to study the effects of SLR on ports, despite a number of calls for more research to be done on the subject (Becker et al., 2013).

\section{METHODOLOGY}

The authors conducted a large number of field surveys through the areas to document the measures that different areas around the world area adopting to adapt to relative sea level rise (see Takagi et al., 2016, Esteban et al., 2015, etc).

The present work continues the line of work employed by the authors by conducting field surveys of ports and other docking areas that have been raised following land subsidence. Key informant interviews were conducted with port officials and other stakeholders, in order to determine the types of measures that were attempted. These semi-structured interviews typically lasted for about an hour, and were held between authors and any number of port employees that were willing to participate in them. For the case of the Indonesia ports, two of the authors of the study served as interpreters to the other authors present. For the case of the Japanese ports the main author and other authors conducted communication directly in Japanese. Both Indonesian and Japanese engineers spoke some English, and some communication was also conducted in this language. The interview generally started by asking some general questions about the port (size, main activities, current estate of reconstruction), and then moved onto questions regarding the cost of adaptation measures against land subsidence.

\section{RESULTS}

The results indicate that the preferred adaptation mechanism appears to be the elevation of port areas by piling any available soil or rubble, and then re-surfacing to obtain a smooth surface (see Fig. 1 and 2). While these results would appear obvious, they provide real evidence and lessons for other ports that will inevitable have to attempt similar adaptation strategies in the future.

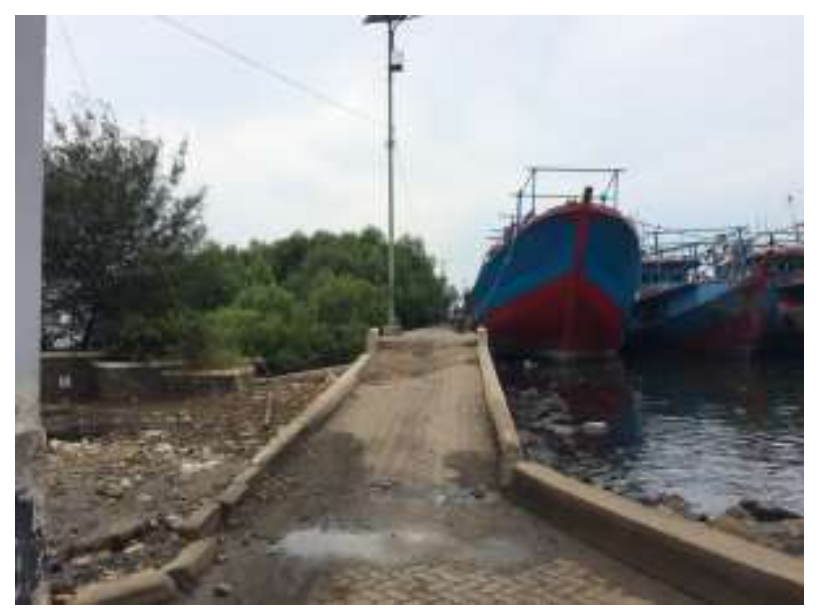

Figure 1 - Port adaptation to SLR in Jakarta: raising wharfs 


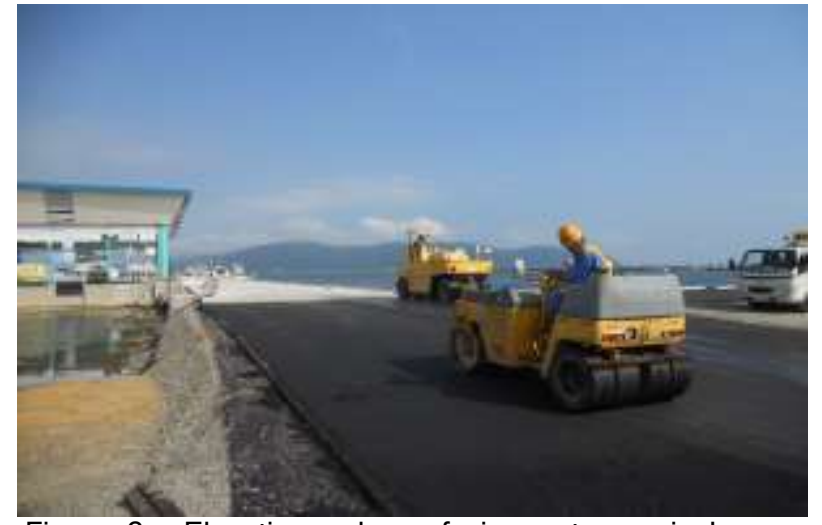

Figure 2 - Elevating and resurfacing port areas in Japan

The authors also asked respondents to indicate the perceived limits to adaptation against a range of SLR scenarios (see Table 1). The most critical respondents were those in Japan, who highlighted how earthquake considerations would limit adaptation to up to $+1.0 \mathrm{~m}$ SLR, before additional (more expensive) countermeasures had to be employed.

Table 1. Perception of different limits to adaptation by port officials at Ishinomaki port. Green indicates no perceived limits, yellow indicates the beginning of problems, red the limits to adaptation.

\begin{tabular}{|l|l|l|l|l|}
\hline $\begin{array}{c}\text { Sea } \\
\text { Level } \\
\text { Rise }\end{array}$ & $\begin{array}{c}\text { Technological } \\
\text { Limits }\end{array}$ & $\begin{array}{c}\text { Cost- } \\
\text { Benefit } \\
\text { Limits }\end{array}$ & $\begin{array}{c}\text { Financial } \\
\text { Barriers }\end{array}$ & $\begin{array}{c}\text { Social } \\
\text { Conflict } \\
\text { Barriers }\end{array}$ \\
\hline+ & & & & \\
$0.5 \mathrm{~m}$ & & & & \\
\hline+ & & & & \\
$0.51-$ & & & \\
$1.0 \mathrm{~m}$ & & & & \\
\hline+ & Earthquake & & & \\
$1.01-$ & considerations & & & \\
$2.0 \mathrm{~m}$ & & & & \\
\hline+ & Earthquake & & & \\
$2.01-$ & considerations & & & \\
$\mathbf{4 . 0 \mathrm { m }}$ & & & \\
\hline+ & Earthquake & & Better to & \\
$4.01-$ & considerations & & relocate? & \\
$\mathbf{8 . 0 \mathrm { m }}$ & & & \\
\hline
\end{tabular}

\section{CONCLUSIONS}

By studying how ports have adapted to land subsidence in Japan and Indonesia, it is possible to try to understand the effects that future SLR will have on such critical transport infrastructure.

While adaptation might result in additional costs that would not be incurred if more stringent mitigation strategies were employed, there seems to be no significant technological limits to adaptation in ports, at least for the SLR that is likely to take place in the $21^{\text {st }}$ century.

Nevertheless, the port operators interviewed did highlight a number of important considerations, and how such issues are likely to impact on the finance and operations of the various ports in the middle and longterm. It is important to take these into account to inform future adaptation strategies in other port, and in order to highlight the importance of more stringent mitigation targets, to avoid such additional costs to human societies.

\section{REFERENCES}

Bars, D. L., Drijfhout, S. and Vries, H. (2018) A high-end sea level rise probabilistic projection including rapid Antarctic ice sheet mass loss. Environmental Research Letters, 12, 044013.

Becker et al. (2013) "A note on climate change adaptation for seaports: A challenge for global ports, a challenge for global society", Journal of Climatic Change 120, 683-695

Esteban, Onuki, Ikeda, Akiyama, T. (2015)

"Reconstruction Following the 2011 Tohoku Earthquake Tsunami: Case Study of Otsuchi Town in Iwate Prefecture, Japan" in Handbook of Coastal Disaster Mitigation for Engineers and Planners. Esteban, M., Takagi, H. and Shibayama, T. (eds.). ButterworthHeinemann (Elsevier), Oxford, UK

Esteban, M., Takagi, H., Mikami, T., Aprilia, A., Fujii, D., Kurobe, S. and Utama, N. A. (2017) "Awareness of coastal Floods in Impoverished Subsiding Coastal Communities in Jakarta: Tsunamis, Typhoon Storm Surges and Dyke-Induced Tsunamis", International Journal of Disaster Risk Reduction 23, 70-79

Jamero, L., Esteban., M. and Onuki, M. (2016) "Potential In-Situ Adaptation Strategies for Climate-Related SeaLevel Rise: Insights from a Small Island in The Philippines Experiencing Earthquake-Induced Land Subsidence", J-SustaiN 4 (2) pp 44-53.

Jamero, L., Onuki, M. and Esteban, M., Billones-Sensano, X. K., Tan, N., Nellas, A., Takagi, H., Thao, N. D. and Valenzuela, V. P. (2017) "Small island communities in the Philippines prefer local measures to relocation in response to sea-level rise", Nature Climate Change 7, $581-586$

Jamero, L., Onuki, M., Esteban, M. and Tan, N. (2018) "Community-based adaptation in low-lying islands in the Philippines: Challenges and lessons learned", Regional Environmental Change (accepted)

Kopp, R. E., DeConto, R. M., Bader, D. A., Hay, C. C., Horton, R. M., Kulp, S., Oppenheimer, M., Pollard, D. and Strauss, B. H. (2017) Evolving Understanding of Antarctic Ice-Sheet Physics and Ambiguity in Probabilistic SeaLevel Projections. Earth's Future, 5, 1217-1233

Takagi, Fujii, Esteban, Yi (2017) "Effectiveness and Limitation of Coastal Dykes in Jakarta: the Need for Prioritising Actions against Land Subsidence". Sustainability 9, 619

Takagi, H., Fujii, D., Mikami, T. and Esteban, M. (2016) "Mangrove Forest against Dyke-break induced Tsunami in Rapidly Subsiding Coasts", Natural Hazards and Earth System Science, 16, 1629-1638.

Vermeer and Rahmstorf (2009) Global sea level linked to global temperature. PNAS;106:21527-21532

Yamamoto, L. and Esteban, M. (2016) "Migration as an Adaptation Strategy for Atoll Island States". Journal of International Migration 55 (2) pp. 144-158 